\section{Consumer Interest in Fresh, In-shell Edamame and Acceptance of Edamame-based Patties}

\author{
Dru N. Montri ${ }^{1}$, Kathleen M. Kelley ${ }^{2,3}$, and Elsa S. Sánchez ${ }^{2}$ \\ Department of Horticulture, The Pennsylvania State University, University \\ Park, PA 16802
}

Additional index words. consumer research, edamame, in-store survey, sensory evaluation

\begin{abstract}
Two studies were conducted to determine consumer interest in fresh, in-shell edamame [Glycine max (L.) Merrill] and acceptance of two edamame-based patties. An in-store consumer research study was conducted in metropolitan Philadelphia to determine consumer demand for and interest in fresh, in-shell edamame. In fall 2004, plastic clamshells of edamame were placed in the produce department of four supermarkets. Consumers who purchased the clamshells were asked to return a survey that was attached to the container. Of the $\mathbf{4 8 0}$ clamshells that were delivered to the four selected supermarkets, $312(65.0 \%)$ were purchased and $33(10.6 \%)$ of the surveys were returned. All respondents indicated that they had heard of or were familiar with edamame before purchasing the container, and $81.2 \%$ had previously purchased edamame. Results indicate that $51.6 \%$ of respondents were more likely to purchase the edamame because it was grown in Pennsylvania, and $84.4 \%$ were more likely to purchase it because it was grown without the use of pesticides. In addition, a friend's recommendation, price, and sample of the product at the supermarket were rated highest among factors likely to affect respondents' purchasing decisions regarding new produce items. Based on the total number of packages sold and conversations with produce department managers, there appears to be a demand for fresh, in-shell edamame among supermarket consumers in metropolitan Philadelphia. A second study involving a consumer sensory evaluation was conducted in Feb. 2005 to determine consumer acceptance of two edamame-based patties. A total of 209 adults were involved, with 106 participants sampling the edamame-based patties on the first day and 103 sampling on the second day. Participants were asked to rate the patty they sampled on overall appeal, appearance, and flavor on a scale of 1 to 9 points ( 1 point being "dislike extremely" and 9 points being "like extremely"). Overall mean liking for the two patties was 6.38 points and 6.58 points, and mean liking for flavor was 6.44 points and 6.83 points on days 1 and 2 respectively. Based on the sample evaluated, $43.4 \%$ and $35.9 \%$ of participants, each day, indicated that they "probably would buy" or "definitely would buy" this item from a supermarket. Results suggest that consumers found the two edamame-based patties acceptable, indicating the potential for commercial production. Across the two studies, consumers expressed interest in purchasing fresh, in-shell edamame and edamame-based patties from a supermarket.
\end{abstract}

Edamame [Glycine $\max ($ L.) Merrill], or green vegetable soybeans, are the same species as agronomic soybeans, but are cultivars selected for their sweet, mild flavor and nutty texture (Yinbo et al., 1997). Edamame contain lower levels of trypsin inhibitors, fewer indigestible oligosaccharides, a greater

Received for publication 4 May 2006. Accepted for publication 28 July 2006.

Funded by the U.S. Department of Agriculture Federal-State Marketing Improvement Program. Use of trade names does not imply endorsement of the products named or criticism of similar ones not named.

We thank Ruth Hollender and Julie Peterson, Sensory Evaluation Laboratory, Department of Food Science, Pennsylvania State University, for their assistance with the sensory evaluation.

${ }^{1}$ Graduate Research Assistant.

${ }^{2}$ Assistant Professor.

${ }^{3}$ To whom reprints should be addressed; e-mail kmk17@psu.edu amount of vitamins (Rackis, 1978), and higher levels of phytic acid (Gupta et al., 1976) than agronomic soybeans. Edamame can be marketed frozen or fresh; however, the majority of edamame currently sold in supermarkets across the United States is frozen. Frozen edamame has greater flexibility in direct and Internet-based marketing systems than fresh edamame (Nelson et al., 2001), because it has a storage life of 7 to 9 months (Johnson, 2000). Fresh edamame is substantially less available in the United States as opposed to frozen edamame, prompting food brokers to identify it as one of the products in highest demand but hardest to find (Ernst and McNulty, 2001). As of 2000, interest in fresh, in-shell edamame in the United States has increased (Johnson, 2000) and demand may increase even more over time as consumers become increasingly aware of the health benefits associated with eating edamame (Nelson et al., 2001). Health benefits from eating soy foods like edamame can include strong bones and teeth and lower cholesterol levels
(Messina, 2001). It was also thought to aid in the prevention of cardiovascular disease and in the reduction in mammary and prostrate cancers (Messina, 2001). However, the American Heart Association recently released a statement indicating that recent studies did not show that soy protein had any specific action on heart risk factors and that the efficacy for soy isoflavones preventing mammary and prostate cancers are not established. The statement suggested that consuming soy could be beneficial if replacing other high-fat proteins because of the high content of polyunsaturated fats, low content of saturated fat, fiber, vitamins and minerals and the (Sacks et al., 2006).

Consumers in the United States, on average, visit a grocery store 2.2 times per week, spending an average of $\$ 92.50$ per household (Anonymous, 2005), which translates to $\$ 430$ billion dollars spent each year at $\approx 34,000$ supermarkets (Lubove, 2005). Because supermarkets are the primary destination for purchasing groceries, introducing fresh edamame into a supermarket produce department could be a potentially successful marketing avenue. However, consumer awareness and acceptance should be addressed in a marketing program before introducing an item into retail outlets (Miles and Alleman, 2001), and defining consumer preferences for edamame will assist in developing an effective marketing plan (Kelley and Sánchez, 2005). Determining which consumers would purchase fresh, in-shell edamame from supermarkets and how it would be used is important when assessing potential marketability. In addition, determining why consumers choose to purchase the items they do can be used to produce other edamame-based products and can target consumer segments most likely to buy these items, resulting in higher sales (Glanz et al., 1998).

Edamame also has the potential to be processed into value-added convenience products that could be marketed through a supermarket's prepared foods section or deli. Many consumers who purchase or cook with unprocessed produce are willing to pay more for convenience (Sloan 2003). A survey conducted by Vance Research Services (Lincolnshire, Ill.) found that $69 \%$ of consumers in the United States try to make cooking as easy as possible. In addition, $40 \%$ of consumers buy foods that are quick and easy to prepare, and $31 \%$ will pay more for foods that are convenient to prepare (Anonymous, 2001). These statistics help to explain why many supermarkets are focusing on prepared meals and convenience items. For example, Whole Foods Market ${ }^{\circledR}$, founded in Austin, Texas, derives about two-thirds of its sales from perishables and prepared meals. Products prepared on-site allow retailers to acquire a premium over the sale of the unprepared item. For example, the price for $454 \mathrm{~g}$ of chicken that may regularly sell for $\$ 2$ to $\$ 3$ may sell for $\$ 10.29$ when it is grilled with rosemary (Lubove, 2005).

According to Japanese quality standards, edamame sold in the shell should have 
a minimum of two beans per pod, be bright green in color, and be unblemished (Shanmugasundaram, 1991). Beans from pods that do not meet these standards could potentially be used for processing, where pod standards no longer apply, enabling producers to capture an even larger market segment (Miles and Alleman, 2001). Although there is an array of value-added products in which edamame could be used, one such product is an edamame-based patty, similar in concept to a veggie burger. A veggie burger, also referred to as a garden burger, is a burger made without meat or animal ingredients. Patties are mainly composed of vegetables, nuts, or textured vegetable protein. While developing a new product, it is beneficial to have consumers evaluate prototypes to increase the probability of its acceptance and resulting competitiveness in the marketplace, considering the success rate for newly introduced products is less than $10 \%$ in the first year (Hollingsworth, 1996).

Consumer acceptance testing for a product in a preliminary developmental stage should precede larger scale testing. Using this type of sensory test allows researchers to measure liking or preference for a product, which is a necessary step before investing substantial capital in large-scale testing and the production and promotional efforts that follow. There is also a vital link between sensory testing and marketing research. Sensory testing focuses on the product, whereas marketing research focuses on identifying consumers who find the product appealing and developing promotional materials based on particiSidel, 2004). Demographic and sociographic variables can also be used to find out who might purchase the product being evaluated (Kelley and Sánchez, 2005).

Objectives for this research were to 1) understand potential demand for fresh, inshell edamame in metropolitan Philadelphia supermarkets; 2) determine consumer acceppant responses to survey questions (Stone and

tance of two types of edamame-based patties; and 3) establish criteria that are important to consumers when choosing and purchasing new produce items such as fresh, in-shell edamame or edamame-based products.

\section{Materials and Methods}

Study 1: Fresh edamame in metropolitan Philadelphia supermarkets. Four supermarkets located in metropolitan Philadelphia were chosen from a listing of six chain stores owned by a Texas-based natural and organic foods supermarket company. Metropolitan Philadelphia was selected because it is an area with diverse demographics including ethnicity, income, and education level (Ligos, 2003). The four stores were located in Montgomery and Philadelphia counties. Demographic characteristics including age, education attainment, household income and size, and ethnicity of the residents in the area surrounding each of the four supermarkets are listed in Table 1.

Edamame were packaged in $340 \mathrm{~g}$ portions and placed into $454 \mathrm{~g}$ Mixim clamshells (Sambrailo Packaging, Watsonville, Calif.). A $10.2 \times 3.4-\mathrm{cm}$ label was placed on the top of each container and included the name of a fictitious company (Emerald Acres), the scientific and common names for edamame, a statement indicating the beans were grown pesticide free and in Pennsylvania, package weight, a freshness date, a contact telephone number for the researchers, and a UPC number and barcode. The UPC number was determined in conjunction with the Produce Marketing Association (Newark, Del.), and Bar Code Publisher ${ }^{\circledR}$ (TEKLYNX Software Solutions, Milwaukee, Wis.) was used to develop the barcode. An edamame recipe obtained from a professional chef marketing study conducted in 2003 (Montri et al., 2005), a consent statement, a follow-up survey, and an addressed, postage-paid reply envelope

Table 1. Demographic summary for the area within a 5-mile radius of the four metropolitan Philadelphia supermarkets selected for the in-store study of consumer interest and demand for edamame conducted from 1 Sept. to 13 Oct. 2004.

\begin{tabular}{|c|c|c|c|c|}
\hline & \multicolumn{4}{|c|}{ County } \\
\hline & \multicolumn{2}{|c|}{ Montgomery } & \multicolumn{2}{|c|}{ Philadelphia } \\
\hline & Store 1 & Store 2 & Store 1 & Store 2 \\
\hline City & Jenkintown & Wynnewood & Philadelphia & Philadelphia \\
\hline Population & $268,342^{z}$ & 600,864 & 951,243 & 846,080 \\
\hline Median age $(y)$ & 40.6 & 34.7 & 32.1 & 32.2 \\
\hline \multicolumn{5}{|c|}{ Education attainment (pop. $25+$ ) } \\
\hline Less than high school & $12.4 \%$ & $20.3 \%$ & $33.7 \%$ & $34.7 \%$ \\
\hline High school & $30.6 \%$ & $28.9 \%$ & $30.6 \%$ & $31.0 \%$ \\
\hline Some college & $17.7 \%$ & $16.6 \%$ & $14.4 \%$ & $14.3 \%$ \\
\hline Associate degree & $6.1 \%$ & $5.0 \%$ & $3.8 \%$ & $3.7 \%$ \\
\hline College & $20.1 \%$ & $16.0 \%$ & $9.4 \%$ & $8.8 \%$ \\
\hline Graduate degree & $13.1 \%$ & $13.2 \%$ & $8.0 \%$ & $7.4 \%$ \\
\hline Median household income & $\$ 54,305$ & $\$ 36,298$ & $\$ 25,751$ & $\$ 25,309$ \\
\hline Median household size & 2.7 & 2.6 & 2.6 & 2.6 \\
\hline \multicolumn{5}{|l|}{ Ethnicity } \\
\hline White & $88.0 \%$ & $48.6 \%$ & $33.0 \%$ & $34.3 \%$ \\
\hline Black & $5.7 \%$ & $44.7 \%$ & $52.4 \%$ & $50.9 \%$ \\
\hline Hispanic & $2.2 \%$ & $1.6 \%$ & $12.2 \%$ & $12.7 \%$ \\
\hline Asian, Pacific Islander & $4.2 \%$ & $4.2 \%$ & $4.7 \%$ & $4.6 \%$ \\
\hline Other & $2.1 \%$ & $2.4 \%$ & $9.9 \%$ & $10.1 \%$ \\
\hline
\end{tabular}

${ }^{\mathrm{z}}$ Data derived from Easy Analytic Software, Inc. (Bellmawr, N.J.) as of 1 Apr. 2000 and are based on the 2000 U.S. Census. were placed in a sealed plastic bag (Fisher Scientific, Chicago, Ill.) and attached to the bottom of each container. Each survey was coded to correspond to the store and date it was delivered (Kelley et al., 2002). A retail price of $\$ 2.49$ was assigned to the packages, a price that was competitive with similarly packaged fresh vegetables and greater than that of frozen, conventionally grown edamame.

Thirty clamshells were delivered to each store every Wednesday over a 4-week period from 1 Sept. to 6 Oct. 2004. Clamshells of edamame were displayed in the produce section of each store near similar products, such as specialty green beans and sugar snap peas packaged in comparable plastic clamshells. Edamame clamshells remained in the stores for 1 week and were removed from the display when the next delivery arrived. A total of 480 clamshells were delivered during the study.

Participants were self-selected for the survey by purchasing the clamshell of edamame. Consumers who purchased the edamame and responded to the follow-up survey were asked to indicate their reasons for purchasing the edamame and to describe their purchasing habits regarding new produce items they find at supermarkets. Additional survey questions asked participants to 1) describe their purchasing habits regarding vegetables based on claims that eating the vegetable may decrease their risk of cancer or other diseases, 2) express their familiarity with edamame as a produce option, 3) provide their opinion of the sample recipe provided, 4) indicate their use of the edamame they purchased, 5) offer comments regarding the container packaging and visibility in the produce department, and 6) provide demographic information including gender, age, level of education, ethnicity, household size, annual household income, and zip code.

The protocol and survey instrument were approved by the Office for Research Protections and Biomedical Institutional Review Board at The Pennsylvania State University. Data were pooled to create a larger data set for interpreting the respondents' survey answers (Kelley et al., 2002). Descriptive statistics were used to evaluate survey results.

Study 2: Consumer acceptance of edamame-based patties. A consumer sensory evaluation was administered on 9 and $10 \mathrm{Feb}$. 2005 at the Sensory Evaluation Laboratory on The Pennsylvania State University, University Park campus, to determine consumer acceptance of two types of edamame-based patties. This tool is a cost-effective screening method that can be very useful before largescale production commitments (Stone and Sidel, 2004). The two patties were mainly composed of edamame, mushrooms, and onion; however, they differed in the type of mushroom and seasonings used and in the addition of walnuts to one of the recipes. An edamame, button mushroom, and walnut patty was sampled on 9 Feb. 2005 and an edamame and Portobello patty was sampled 
on 10 Feb. 2005. Shelled (beans removed from pods) edamame (Sunrich Naturals, Hope, Minn.) were purchased from a local supermarket in $340 \mathrm{~g}$ packages and used in this study.

While developing the edamame-based patties, recipes for other vegetable-based patties were evaluated and then modified to include edamame. Two patties showed the most promise with regard to flavor, appearance, and texture, and were used in a pilot study involving 23 participants. About 70\% of participants liked both patties (data not shown). During the pilot study, a traditional hamburger bun was used as a carrier or vehicle (Lawless and Heymann, 1998) for the edamame patties. Because these types of patties are likely to be served in a style similar to a burger, the use of a carrier was important. Based on participant comments, the carrier was changed to pocket bread (Father Sam's, Buffalo, N.Y.) to reduce the association between a traditional hamburger bun and meat-based patties. Condiments, such as ketchup or mustard, were not used to avoid masking patty characteristics (Lawless and Heymann, 1998). Additionally, changes were made to the patties to improve the texture and flavor.

Patties were prepared the day before the sensory evaluation and refrigerated at $5{ }^{\circ} \mathrm{C}$ overnight. On the day of the evaluation, patties were baked at $204{ }^{\circ} \mathrm{C}$ for $20 \mathrm{~min}$ and then placed on a warming tray for an additional $15 \mathrm{~min}$ before serving. Patties were held on the warming tray for up to an additional 30 min before being replaced with a fresh batch. Samples weighing $57 \mathrm{~g}$ were placed on pocket bread immediately before serving. One type of patty was evaluated each day to avoid comparisons between the two.

The consumer sensory evaluation consisted of 1) questions that allowed the participant to evaluate the sample overall and appearance, flavor, and texture of the patty; and 2) consumer research questions regarding behavioral and demographic information. Compusense five version 4.6 (Compusense, Guelph, Ontario), a sensory and consumer research data collection program, was used to administer the survey. The protocol and survey instrument were approved by the Office for Research Protections and Biomedical Institutional Review Board at The Pennsylvania State University.

Participants were recruited from the university and local community through e-mail and personal invitation. All participants were prescreened to meet specific sensory requirements that were believed to be sufficient to represent a target population (Hampson et al., 2000), including future potential edamamebased patty consumers. Potential participants were informed that the laboratory was evaluating vegetable-based patties, similar in concept to a veggie burger, to determine whether this type of product appealed to them. If their answer to the screener criterion was positive, they were asked to participate.

Each participant was given a consent form that included an ingredient list to read and sign to participate. If participants had a food allergy to any of the ingredients listed, they were asked not to participate. Participants were then given a sample tray that contained a napkin, an $\approx 150 \mathrm{ml}$ glass of water, and the edamame-based patty sample. They were then instructed to sit at a computer-equipped booth and to begin the sensory evaluation by using either the mouse or keyboard to select their responses from the computer screen. Participants were asked to rate the patty overall and then rate the appearance and flavor on a scale of 1 to 9 points (1 point being "dislike extremely" and 9 points being "like extremely"). A 9-point hedonic scale was used to measure likability, because it is easy to understand with minimal instruction (Stone and Sidel, 2004). Participants then rated the texture of the patty on a just-aboutright scale of 1 to 7 points ( 1 point being "much too soft" and 7 points being "much too firm"). This same scale had previously been used to rate edamame bean firmness in a 2002 edamame sensory evaluation (Kelley and Sánchez, 2005). Participants then responded to consumer research questions addressing whether they were familiar with edamame, if they specifically purchase vegetables based on nutritional content, whether they specifically purchase vegetables based on claims that eating them may decrease their risk of cancer or other diseases, how often they purchase soy or soy-based products, the number of dinners they prepare at home each week, and the amount of time they spend on average preparing dinner. To estimate demand better, participants were asked to answer a question regarding their likelihood to purchase the edamame-based patty. They were also asked to answer sociographic questions regarding whether they were a vegetarian or vegan and whether they were the primary shopper in their household. Demographic questions addressed gender, age, education level, ethnicity, number of adults and children in their household, and their 2004 household income. Upon completion of the consumer sensory evaluation, participants were given $\$ 10$ for their participation (Kelley and Sánchez, 2005).

Answers for consumer marketing questions were merged for the $2-d$ period. Segmented responses were subjected to analysis using the Mann-Whitney $U$ test $(P \leq 0.05)$ to determine differences in behavioral attitudes based on demographic information (SPSS version 12.0, Chicago, Ill.). Friedman analysis of rank $(\alpha=0.05)$ and Tukey's HSD procedure $(\alpha=0.05)$ using Compusense five were used to analyze rankings for the factors that affect the decision to purchase a new food item.

\section{Results and Discussion}

Study 1: Fresh edamame in metropolitan Philadelphia supermarkets. Of the 480 clamshells of edamame that were delivered, $65.0 \%$ were purchased with the total number of clamshells purchased weekly at all four stores ranging from 64 to $88(53.3 \%-73.3 \%)$ and the number of clamshells purchased at individual stores throughout the 4-week period ranging from 47 to $102(39.2 \%-85.0 \%)$. None of the stores involved reported any returns or requests for refunds. Produce department managers commented that they were happy with the number of packages sold and thought the numbers would increase, as a result of consumer recognition, if the edamame was in the store longer than a 4week period. These department managers also indicated that they would be willing to work with small-acreage growers interested in producing edamame for the fresh market.

Thirty-three surveys were returned, resulting in a $10.6 \%$ response rate, which is similar to the $11 \%$ typical response rate for a direct-mail survey (Reed, 1999). The number of survey responses was similar over time and between stores (data not shown).

Participants responded to questions regarding demographic characteristics indicating that $87.5 \%$ were female, $65.6 \%$ were younger than 47 years of age, $96.9 \%$ had completed at least some college, $87.1 \%$ lived in households with two or more adults, and $58.1 \%$ lived in household containing no children (Table 2).

Results indicate that $51.6 \%$ of respondents were more likely to purchase the edamame because it was grown in Pennsylvania and $84.4 \%$ were more likely to purchase it because it was grown without the use of pesticides. In addition, $56.2 \%$ of respondents currently purchase vegetables based on claims that eating the vegetable may decrease their risk of cancer or other diseases and $83.9 \%$ would be willing to purchase a new vegetable if similar evidence was available. In the future, respondents would prefer to purchase edamame in-shell $(48.5 \%)$ or both in-shell and shelled (48.5\%).

All respondents had heard of or were familiar with edamame before purchasing the container, and $82.1 \%$ had purchased edamame before at supermarkets, natural food stores, farmers markets, or restaurants. They had purchased edamame frozen, fresh, shelled, and in-shell. Each participant had purchased soy or soy-based products and regularly consumed Chinese, Japanese, or Korean foods. All survey participants had a 2003 household income of more than $\$ 40,000$, and $84.4 \%$ indicated that the category white/Anglo best described their ethnicity. The majority $(93.8 \%)$ of respondents were the primary food shoppers in their household and $15.6 \%$ were vegetarian or vegan. Seventy-nine percent of respondents served the edamame as an appetizer or side dish and only one of the respondents prepared the sample recipe that was attached to the bottom of the container (data not shown).

Respondents were also asked to rate on a scale of 1 to 7 points (1 point being "very unlikely" and 7 points being "very likely"), how likely select factors affect their decision to purchase a new produce item: packaging, price, sample of the product at a supermarket, recipe card or recipe on the package, in-store signage, television advertisements, friend's 
Table 2. Demographic information and responses to behavioral questions asked on a survey attached to the edamame clamshell purchased at four supermarkets in metropolitan Philadelphia between 1 Sept. and 13 Oct. 2004.

\begin{tabular}{|c|c|c|}
\hline & No. of responses $(n=31-33)$ & Valid \% \\
\hline \multicolumn{3}{|l|}{ Gender } \\
\hline Male & 4 & 12.5 \\
\hline Female & 28 & 87.5 \\
\hline \multicolumn{3}{|l|}{ Age } \\
\hline$\leq 47 \mathrm{y}$ & 21 & 65.6 \\
\hline$\geq 48 \mathrm{y}$ & 11 & 34.4 \\
\hline \multicolumn{3}{|l|}{ Ethnicity } \\
\hline White/Anglo & 27 & 84.4 \\
\hline Black/African American & 0 & 0 \\
\hline Native American/American Indian & 0 & 0 \\
\hline Asian American & 3 & 9.4 \\
\hline Hispanic/Latino American & 1 & 3.1 \\
\hline Pacific Islander & 0 & 0 \\
\hline Other & 1 & 3.1 \\
\hline \multicolumn{3}{|l|}{ Education level } \\
\hline Some high school & 0 & 0.0 \\
\hline High school graduate & 1 & 3.1 \\
\hline Some college & 3 & 9.3 \\
\hline Associate degree or technical school graduate & 2 & 6.3 \\
\hline Bachelor's degree & 11 & 34.4 \\
\hline Professional degree & 2 & 9.3 \\
\hline Master's degree & 6 & 18.8 \\
\hline Doctorate degree & 6 & 18.8 \\
\hline \multicolumn{3}{|l|}{ Household members $\geq 18 \mathrm{y}$} \\
\hline 1 per household & 4 & 12.9 \\
\hline$\geq 2$ per household & 27 & 87.1 \\
\hline \multicolumn{3}{|l|}{ Household members $<18$ y } \\
\hline 0 per household & 18 & 58.1 \\
\hline$\geq 1$ per household & 13 & 41.9 \\
\hline \multicolumn{3}{|l|}{ Primary food shopper in household } \\
\hline Yes & 30 & 93.8 \\
\hline No & 2 & 6.2 \\
\hline \multicolumn{3}{|l|}{ Vegetarian or vegan } \\
\hline Yes & 5 & 15.6 \\
\hline No & 27 & 84.4 \\
\hline \multicolumn{3}{|l|}{ Purchased edamame before } \\
\hline Yes & 26 & 81.2 \\
\hline No & 6 & 18.8 \\
\hline \multicolumn{3}{|l|}{$\begin{array}{l}\text { More likely to have purchased the edamame } \\
\text { because it was grown in Pennsylvania }\end{array}$} \\
\hline Yes & 16 & 51.6 \\
\hline No & 15 & 48.4 \\
\hline \multicolumn{3}{|l|}{$\begin{array}{l}\text { More likely to have purchased the edamame } \\
\text { because it was grown pesticide free }\end{array}$} \\
\hline Yes & 27 & 84.4 \\
\hline No & 5 & 15.6 \\
\hline \multicolumn{3}{|l|}{$\begin{array}{l}\text { Specifically purchase vegetables based on } \\
\text { claims that eating the vegetable may decrease } \\
\text { their risk of cancer or other diseases }\end{array}$} \\
\hline Yes & 18 & 56.2 \\
\hline No & 14 & 43.8 \\
\hline \multicolumn{3}{|l|}{$\begin{array}{l}\text { Would be willing to purchase a vegetable } \\
\text { they had never eaten before if there } \\
\text { was evidence that eating it may decrease } \\
\text { their risk of cancer or other diseases }\end{array}$} \\
\hline Yes & 26 & 83.9 \\
\hline No & 5 & 16.1 \\
\hline \multicolumn{3}{|l|}{$\begin{array}{l}\text { In the future would prefer to buy } \\
\text { edamame as }\end{array}$} \\
\hline In-shell only & 16 & 48.5 \\
\hline Shelled only & 1 & 3.0 \\
\hline Both in-shell and shelled & 16 & 48.5 \\
\hline
\end{tabular}

recommendation, health benefits stated on the package, magazine or news article, informative brochure, store circular, and instore cooking demonstrations (Table 3). Select factors were distinguished as in-store promotions, outside advertising, and product packaging. A friend's recommendation received the highest rating among all factors. For in-store promotions, a sample of an item
Table 3. Mean likeliness of factors affecting in-store survey participants' decisions to purchase new produce items from supermarkets $(\mathrm{n}=30-32)$.

\begin{tabular}{lc}
\hline Factors & $\mathrm{Mean}^{2} \pm \mathrm{SD}$ \\
\hline $\begin{array}{l}\text { Friend's recommendation } \\
\text { Price }\end{array}$ & $5.55 \pm 1.48$ \\
$\begin{array}{l}\text { In-store promotions } \\
\quad \text { Sample of produce at }\end{array}$ & $4.97 \pm 1.82$ \\
$\quad$ supermarket & $4.97 \pm 1.88$ \\
$\quad$ In-store cooking & \\
$\quad$ demonstration & $4.44 \pm 1.78$ \\
$\quad \begin{array}{l}\text { In-store signage } \\
\quad \text { Store circular }\end{array}$ & $4.23 \pm 1.71$ \\
Outside advertising & $3.55 \pm 1.61$ \\
$\quad \begin{array}{l}\text { Magazine or news article } \\
\text { Informative brochure }\end{array}$ & $4.78 \pm 1.72$ \\
$\quad \begin{array}{l}\text { Television advertisement } \\
\text { Product packaging }\end{array}$ & $4.41 \pm 1.76$ \\
$\quad$ Health benefits & $2.55 \pm 1.41$ \\
$\quad$ stated on package & \\
$\quad \begin{array}{l}\text { Overall packaging } \\
\text { Recipe card }\end{array}$ & $4.74 \pm 1.84$ \\
$\quad$ or recipe on package & $3.91 \pm 1.86$ \\
\hline
\end{tabular}

${ }^{\text {zScale: }} 1$ to 7 points with 1 point being very unlikely and 7 points being very likely.

recipe card or recipe on the package was rated lowest for product packaging, supporting results from the first study on the topic of fresh edamame in supermarkets in which only one of the respondents prepared the sample recipe that was attached to the bottom of the container.

Among factors that affect consumer's decisions to purchase new produce items from supermarkets, participants rated their friend's recommendation, price, and sample of produce at a supermarket higher than other factors when purchasing new produce items. Although factors in this study were not statistically distinguished from one another, the ranked order is useful in determining factors that could be highlighted for promotional materials.

Overall, a friend's recommendation or word-of-mouth promotion was particularly influential to consumers. This confirms other reports that no advertising or salesperson can convince a consumer about a product as persuasively as a friend, acquaintance, previous customer, or independent expert (Kotler, 2003). When focusing specifically on in-store promotions, the results support the idea that the popularity of sampling and food demonstrations is growing in supermarkets throughout the country. A survey conducted by the polling company ${ }^{\mathrm{TM}}$ (Washington, D.C.) reported that $86 \%$ of consumers surveyed were more likely to purchase a new product if they had the opportunity to sample it first (Engstrom, 2005). Other research suggests that sales can increase $200 \%$ to $400 \%$ for a specific edible product on the day of sampling (Mills, 1998).

To determine more effectively packaging and promotional materials that best attract the attention of potential buyers, open-ended questions addressing the packaging and product visibility were asked. Written comments suggested that buyers liked the clear packaging, the recyclable container, and the portion 
size, but felt simple preparation instructions would have been more beneficial than a recipe. Recommendations for improving the packaging included using a larger label; adding more information to the label, including nutritional value; using a more colorful label or a four-color insert; and increasing the prominence of "Pennsylvania grown." One participant commented, "I hope to continue to see these beans for sale! We love them!"

Study 2: Consumer acceptance of edamame-based patties. Of the 209 participants involved in the 2-d consumer sensory evaluation, $82.1 \%$ and $82.5 \%$ were female on the first and second day respectively. Each day, $\approx 3 \%$ of participants were either vegetarian or vegan and at least $86 \%$ were the primary shopper for their household. On both days, representation for education level was obtained for all categories (some high school, high school graduate, some college, associate degree or technical school graduate, bachelor's degree, professional degree, master's degree, or doctorate degree) except "some high school." On the first day, annual household income ranged from less than $\$ 20,000$ to more than $\$ 160,000$. On the second day, annual household income ranged from less than $\$ 20,000$ to $\$ 119,999$. Each day, more than $84 \%$ of participants were of white/Anglo ethnicity and more than $70 \%$ had no one younger than the age of 18 living in their household.

Consumer evaluation of the sample overall and flavor indicated that the majority of participants liked both patties (Table 4). Overall mean liking for the patties was 6.38 points for the edamame, button mushroom, and walnut patty, and 6.58 points for the edamame and Portobello patty whereas mean liking for flavor was 6.44 points and 6.83 points respectively. Forty-nine percent of participants liked the appearance of the edamame, button mushroom, and walnut patty, and $43.8 \%$ of participants liked the appearance of the edamame and Portobello patty. On the first day, $23.6 \%$ of participants rated the texture of the edamame, button mushroom, and walnut patty as "just about right" whereas $70.7 \%$ rated it as too soft. On the second day, $11.7 \%$ of participants rated the texture of the edamame and Portobello patty as "just about right" whereas $87.4 \%$ rated it as too soft. Verbal comments from some participants after the evaluation included interest in purchasing the edamame-based patty and in obtaining the recipe so they could prepare the patty at home.

Based on the patty they sampled, $43.4 \%$ and $35.9 \%$ of participants, for days 1 and 2 , respectively, indicated that they "probably would buy" or "definitely would buy" this item from a supermarket. Seventy-five percent of participants were not familiar with edamame before this study and $4.8 \%$ were unsure whether they were familiar with edamame, leaving $20.2 \%$ of participants who were familiar with edamame. This percentage of familiarity was much lower than that observed in the supermarket study, in

Table 4. Percentage of consumers that participated in a consumer sensory evaluation on 9-10 Feb. 2005 who liked the sample overall, appearance, and flavor of the edamame-based patties, and the mean score each sensory aspect received.

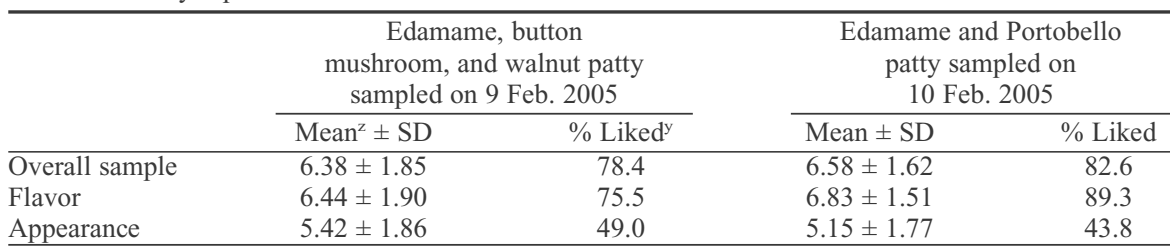

${ }^{z}$ Scale: 1 to 9 points, 1 point being dislike extremely and 9 points being like extremely.

${ }^{y}$ Combined responses for like: extremely, very much, moderately, and slightly.

Patties were sampled independently to avoid comparisons between the two.

which $100 \%$ of participants were familiar with edamame before purchasing it. Although the percentage of participants familiar with edamame was low, participants were familiar with the broader category of soy or soy-based products. More than $75 \%$ of participants had purchased soy or soy-based products before the consumer sensory evaluation.

Responses were segmented based on demographic characteristics including gender, age, education level, and number of people in the household to determine whether one particular group from the criterion-based sample generated more positive responses to certain behavioral questions than their counterpart and were therefore more likely to become a potential buyer (Kelley and Sánchez, 2005).

Females purchase vegetables more often based on nutritional content than males, with $81 \%$ of females indicating that they "always" or "often" purchase vegetables based on nutritional content as opposed to $56 \%$ of males (Table 5). Differences were also found based on the number of children $(<18$ years in age) per household, with $94 \%$ of households containing at least one child, indicating that they "always" or "often" purchase based on nutritional content compared with $70 \%$ of households with no children.

Households consisting of one adult "always" or "often" purchase vegetables based on claims that eating them may decrease their risk of cancer or other diseases $43 \%$ of the time as opposed to $66 \%$ of households containing more than two adults. Participants from households with no children "always" or "often" purchase vegetables based on these claims $54 \%$ of the time compared with $83 \%$ of households with more than one child.

Participants who were not college graduates purchase soy-based products fewer times and prepared fewer meals at home. Thirty-nine percent of college graduates purchase soy-based products two to three times a month or more as opposed to $18 \%$ of those who have not graduated from college. In addition, 95\% of college graduates prepare three or more dinners a week, on average, compared with $82 \%$ of noncollege graduates.

Females prepare more dinners at home each week than males, with $66 \%$ of females preparing five or more dinners at home each week. Eighty-six percent of males spend less than $30 \mathrm{~min}$, on average, preparing for dinner whereas $66 \%$ of females spend less than
$30 \mathrm{~min}$ and $34 \%$ spend between $30 \mathrm{~min}$ and 1 hour preparing for dinner. Participants older than 41 years of age also are more likely to prepare dinners at home compared with participants 40 years of age and younger, with $77 \%$ of participants older than 41 preparing five or more dinners each week.

Three percent of participants were vegetarian or vegan. This percentage is similar to vegetarianism in the United States, in which $2.8 \%$ of the population is vegetarian (Vegetarian Resource Group, 2003). Twenty-five percent of responding vegetarians "always" or "often" purchase vegetables based on nutritional content as opposed to $78 \%$ of nonvegetarians and $0 \%$ of vegetarians who "always" or "often" purchase vegetables based on claims that eating them may decrease their risk of cancer or other diseases compared with $64 \%$ of nonvegetarians. Seventy-five percent of the vegetarian participants spend less than 15 min preparing for dinner, on average. Fourteen percent of nonvegetarians indicated the same.

Participants also ranked select product characteristics that influence their decision to purchase new food items by importance. Criteria were ranked in the same order on both days (Table 6). On the first day, flavor, nutritional value, and price were the highest ranked criteria that influence purchasing decisions. On the second day, the criteria that ranked highest as the most influential when purchasing a food item were flavor, nutritional value, price, and quality. The least preferred criteria on both days were new food item, packaging, and vegetarian item.

Criteria ranked highest by participants indicate important topics to be evaluated in future product and promotional development. Because results from this study indicate the flavor is of prime importance to the consumer, there is potential for the edamamebased patties that were sampled. As shown in Table 4, 75.5\% of participants liked the flavor of the edamame, button mushroom, and walnut patty, and $89.3 \%$ liked the flavor of the edamame and Portobello patty. Nutritional value, price, and quality should also be well regarded in future testing and product improvement, because there are multiple criteria that result in a purchasing decision.

\section{Conclusion}

Introducing edamame into a consumer's diet has the potential to become a prosperous 
Table 5. Effect of gender, age, education level, number of people in household $\geq 18$ years of age, number of people in household younger than 18 years of age, household income, and vegetarianism on participants' answers to questions asked during a sensory evaluation on 9 and 10 Feb. 2005.

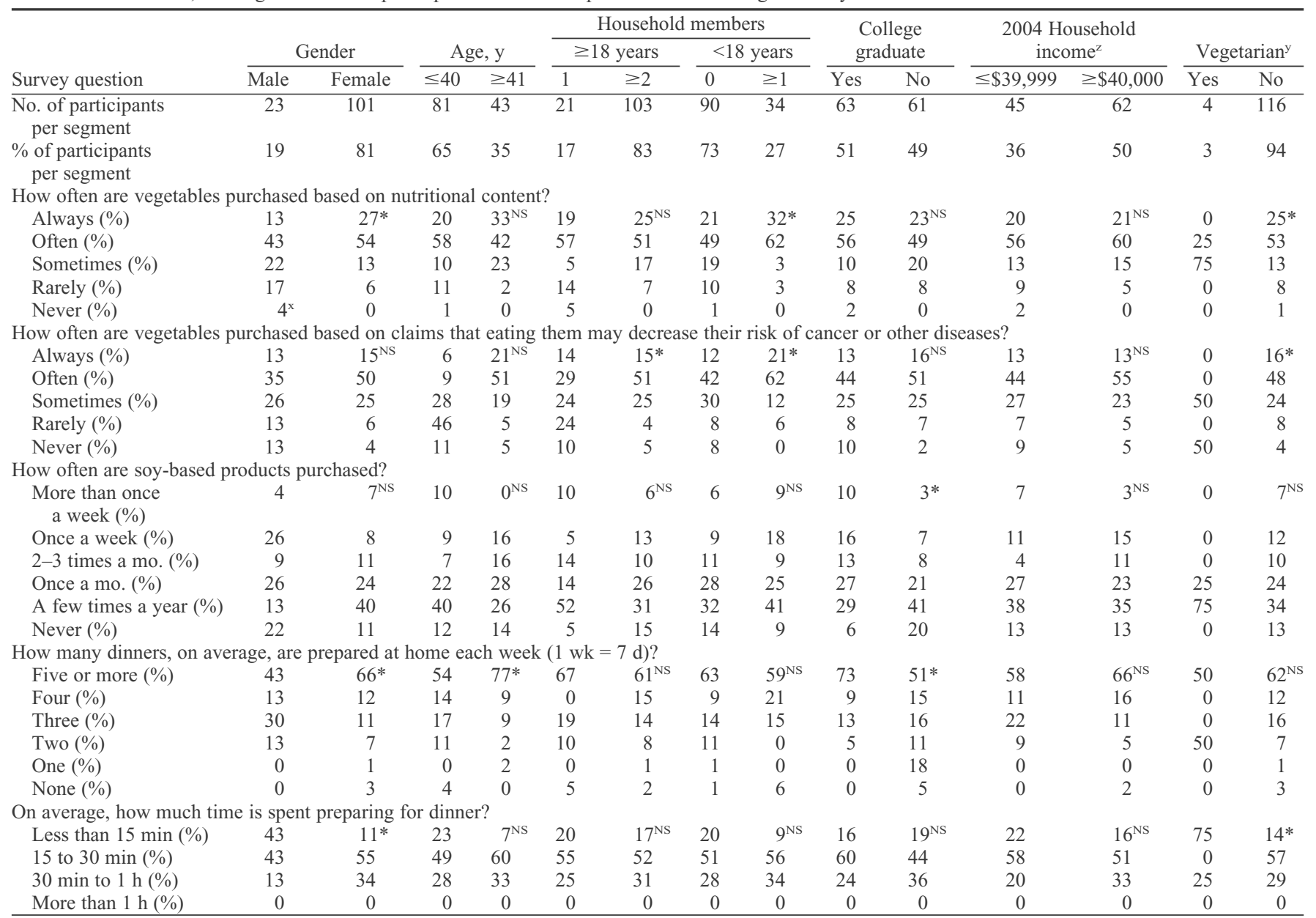

${ }^{\mathrm{z}}$ Seventeen participants preferred not to indicate their 2004 annual household income.

${ }^{\mathrm{y}}$ Four participants indicated that they were unsure whether they were a vegetarian or a vegan.

${ }^{\mathrm{x}}$ Column sums for a survey question may be slightly greater or less than $100 \%$ as a result of rounding.

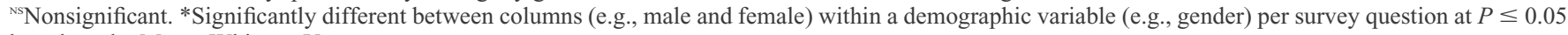
based on the Mann-Whitney $U$ test.

Responses to consumer research questions were combined for the 2-day evaluation period $(n=124)$.

Table 6. Criteria that affect decisions of consumer sensory evaluation participants to purchase a food item ranked in order of importance.

\begin{tabular}{|c|c|c|c|c|}
\hline \multirow[b]{2}{*}{ Criteria } & \multicolumn{2}{|c|}{$\begin{array}{l}\text { Edamame, button mushroom and } \\
\text { walnut patty sampled on } \\
9 \text { Feb. } 2005(\mathrm{n}=106)\end{array}$} & \multicolumn{2}{|c|}{$\begin{array}{l}\text { Edamame and Portobello patty } \\
\text { sampled on } 10 \mathrm{Feb} .2005(\mathrm{n}=103)\end{array}$} \\
\hline & Overall rank & Rank total $^{\mathrm{z}}$ & Overall rank & Rank total \\
\hline Flavor & 1 & $276 \mathrm{a}$ & 1 & $274 \mathrm{a}$ \\
\hline Nutritional value & 2 & $337 \mathrm{ab}$ & 2 & $323 \mathrm{a}$ \\
\hline Price & 3 & $408 \mathrm{abc}$ & 3 & $381 \mathrm{a}$ \\
\hline Quality & 4 & $422 \mathrm{bc}$ & 4 & $410 \mathrm{ab}$ \\
\hline Appearance & 5 & $517 \mathrm{~cd}$ & 5 & $522 \mathrm{bc}$ \\
\hline Convenience & 6 & $580 \mathrm{de}$ & 6 & $550 \mathrm{~cd}$ \\
\hline Advertising & 7 & $668 \mathrm{e}$ & 7 & $674 \mathrm{de}$ \\
\hline New food item & 8 & $836 \mathrm{f}$ & 8 & 788 ef \\
\hline Packaging & 9 & $860 \mathrm{f}$ & 9 & $829 \mathrm{f}$ \\
\hline Vegetarian item & 10 & $926 \mathrm{f}$ & 10 & $914 \mathrm{f}$ \\
\hline
\end{tabular}

${ }^{2}$ Rank totals followed by the same letter are not significantly different using Friedman's analysis of rank and Tukey's HSD procedure $(\alpha=0.05)$.

Rank total based on sum of ranks ( $1=$ most preferred, $10=$ least preferred $)$.

enterprise (Kelley and Sánchez, 2005). Two marketing options include fresh, in-shell edamame for retail sales in supermarkets and edamame-based patties as an addition to a prepared foods department in supermarkets.
Based on conversations with regional produce managers and produce department managers, select supermarkets are willing to work with small-acreage growers interested in producing edamame for the fresh market.
There may be consumer demand for fresh, in-shell edamame in the produce sections of select supermarkets, especially those located in areas with demographics similar to those in the current study. Marketing programs could be adapted to include promotional materials on the growing region (e.g., Pennsylvania grown), production practices (e.g., grown without the use of pesticides), and the health benefits of eating edamame. In-store promotion, specifically, could use sampling to increase sales of a new produce item such as fresh, in-shell edamame.

Beans from pods that do not meet pod quality standards could be used for processing by prepared-food departments in supermarkets. One such item includes edamamebased patties. Results from this study indicate that both types of patties warrant further larger scale testing to determine precise production and marketing requirements.

Overall, a promotional campaign focusing on consumer awareness of edamame and the health benefits associated with eating edamame could be a vital step to introducing these two products for market. 


\section{Literature Cited}

Anonymous. 2001. Cooking attitudes. Produce Merchandising 14:24.

Anonymous. 2005. U.S. grocery shoppers want quality, value, and convenience from multiple retail formats. Progressive Grocer. 3 May 2005. http://www.progressivegrocer.com/progressi vegrocer/magazine/article_display.jsp?vnu_ content_id=1000904364.

Engstrom, T. 2005. Tiny samples yield big profits. The News-Press. 4 Apr. 2005. http:// www.news-press.com/apps/pbcs.dll/article? $\mathrm{AID}=2004404040311$.

Ernst, M. and S. McNulty. 2001. 2001 Edamame marketing fact sheet. Univ. of Kentucky Coop. Ext. 13 July 2003. http://www.uky.edu/Ag/ HortBiz/pubs/facts01 edamame.pdf.

Glanz, K., M. Basil, E. Maibach, J. Goldberg, and D. Snyder. 1998. Why Americans eat what they do: Taste, nutrition, cost, convenience, and weight control concerns as influences on food consumption. J. Amer. Diet. Assoc. 98:1118-1126.

Gupta, A.K., M. Kapoor, and A.D. Deodhar. 1976 Chemical composition and cooking characteristics of vegetable and grain-type soybeans. J. Food Sci. Technol. 13:133-137.

Hampson, C.R., H.A. Quamme, J.W. Hall, R.A. MacDonald, M.C. King, and M.A. Cliff. 2000 Sensory evaluation as a selection tool in apple breeding. Euphytica 111:79-90.

Hollingsworth, P. 1996. Sensory testing and the language of the consumer. Food Technol. 50:65-69.

Johnson, D. 2000. Edamame. Resource 7:11-12.

Kelley, K.M., B.K. Behe, J.A. Biernbaum, and K.L. Poff. 2002. Consumer purchase and use of edible flowers: Results of three studies. HortTechnology 12:282-287.
Kelley, K.M. and E.S. Sánchez. 2005. Accessing and understanding consumer awareness of and potential demand for edamame [Glycine max (L.) Merrill]. HortScience 40:1347-1353.

Kotler, P. 2003. Marketing from A to Z: 80 Concepts every manager needs to know. Wiley, Hoboken, N.J.

Lawless, H.T. and H. Heymann. 1998. Sensory evaluation of food: Principles and practices. Chapman and Hall, New York.

Ligos, M. 2003. 2003 Survey of buying power and media markets. Sales and marketing management. VNU Business Publications, New York.

Lubove, S. 2005. Food porn. Forbes.com. 15 Feb. 2005. http://www.forbes.com/forbes/2005/ 0214/102_print.html.

Messina, M. 2001. An overview of the health effects of soyfoods and soybean isoflavones, p. 117-122. In: T.A. Lumpkin and S. Shanmugasundaram (comp.). Proceedings, Second Int. Vegetable Soybean Conference, Tacoma, WA. 10-12 Aug. 2001. Washington State Univ., Pullman, WA.

Miles, C.A. and D.G. Alleman. 2001. Promoting and marketing Asian crops. HortTechnology 11:517-519.

Mills, P. 1998. Success with produce tasting. Produce Business 14:30-33.

Montri, D.N., K.M. Kelley, and E.S. Sánchez. 2005. Direct marketing Pennsylvania grown edamame to professional chefs in metropolitan Philadelphia: Edamame as a recipe ingredient. The Vegetable and Small Fruit Gazette 9:4.17 May 2005. http://hortweb.cas.psu.edu/ extension/vegcrops/newsletterlist.html.

Nelson, K., R. Smoot, and D. Harder. 2001. Edamame soybean summary (SOY1101). Mis- souri Agricultural Expt. Sta. Greenley Memorial Res. Ctr. 14 Sept. 2003. http://www.rirdc.gov. $\mathrm{au} / \mathrm{pub} / \mathrm{handbook} / \mathrm{edamame} \cdot \mathrm{html}$

Rackis, J.J. 1978. Biochemical changes in soybeans: Maturation, post-harvest storage and processing, and germination, p. 34-76. In: H.O. Hultin and M. Milner (eds.). Post-harvest biology and technology. Food and Nutrition Press, Westport, Conn.

Reed, D. 1999. Mail dominance. Mkt. Week 22:41-45.

Sacks, F.M., A. Lichtenstein, L. Van Horn, W. Harris, P. Kris-Etherton, and M. Winston for the American Heart Association Nutrition Committee. 2006. Soy protein, isoflavones, and cardiovascular health: An American Heart Association science advisory for professionals from the nutrition committee. Circulation: J. Amer. Heart Assn. 113:1034-1044.

Shanmugasundaram, S. 1991. Vegetable soybean: Research needs for production and quality improvement. Workshop Proc. Kenting, Taiwan, 29 Apr.-2 May 1991. Asian Veg. Res. and Dev. Ctr. Publ., 113-119.

Sloan, E. 2003. What, when, and where Americans eat: 2003. Food Technol. 57:48-66.

Stone, H. and J.L. Sidel. 2004. Sensory evaluation practices. 3rd ed. Elsevier Academic Press, San Diego, Calif.

Vegetarian Resource Group. 2003. How many vegetarians are there? 19 June 2005. http:// www.vrg.org/journal/vj2003issue3/vj2003 issue 3 poll.htm

Yinbo, G., M.B. Peoples, and B. Rerkasem. 1997. The effect of $\mathrm{N}$ fertilizer strategy on $\mathrm{N}_{2}$ fixation, growth and yield of vegetable soybean. Field Crops Res. 51:221-229. 